\title{
Perbedaan Kadar Interferon Gamma Cairan Asites pada Subtipe Histopatologi Serosa dan Non-Serosa Kanker Ovarium Tipe Epitel
}

\author{
Anindita Kurniasari ${ }^{1}$, Moh Nailul Fahmi ${ }^{2}$, Nungki Anggorowati ${ }^{3}$ \\ Mahasiswa program sarjana Kedokteran, Fakultas Kedokteran, Kesehatan Masyarakat dan Keperawatan, \\ Universitas Gadjah Mada, Yogyakarta, Indonesia \\ Departemen Obstetri dan Ginekologi FKKMK UGM/RSUP Dr. Sardjito, Yogyakarta, Indonesia \\ ${ }^{3}$ Departemen Patologi Anatomi FKKMK UGM/RSUP Dr. Sardjito, Yogyakarta, Indonesia \\ Korespondensi: kurniasarianindita12@gmail.com
}

Submisi: 15 Maret 2019; Revisi: 16 Agustus 2019; Penerimaan: 19 Agustus 2019

\begin{abstract}
Background: Ovarian carcinoma serous subtype has a better prognosis than non-serous. Interferon gamma (IFN- $\gamma$ ) has a role in prognostic of ovarian carcinoma. IFN- $\gamma$ may have both pro-tumor and anti-tumor activity. There is lack of evidence in determining IFN- $\gamma$ level in ascites and its relationship with serous and non-serous.

Objective: To determine the difference of IFN- $\gamma$ level in ascites in serous and non-serous subtype of ovarian carcinoma.

Methods: The study design was a cross-sectional. Ascites was taken intraoperatively from 11 samples of serous and 7 non-serous ovarian carcinoma patients underwent staging or debulking surgeries from September - December 2018. Ascites were evaluated using ELISA.

Result: The mean of serous ascites IFN- $\gamma$ level was lower $(0.46 \pm 0.35 \mathrm{pg} / \mathrm{ml}(\mathrm{mean} \pm \mathrm{SD}))$ than non-serous $(0.97 \pm 0.88 \mathrm{pg} / \mathrm{ml}(\mathrm{mean} \pm \mathrm{SD}))$, but there is no statistically significant $(p=0.104)$.

Conclusion: There is no significant difference of IFN- $\gamma$ level in ascites on serous and non-serous subtypes of ovarian carcinoma.
\end{abstract}

Keywords: interferon gamma (IFN- - ), ovarian carcinoma, ascites, serous subtypes

\begin{abstract}
ABSTRAK
Latar Belakang: Karsinoma ovarium dapat dibedakan menjadi subtipe serosa dan non-serosa, dimana subtipe serosa memiliki prognosis yang lebih baik. IFN- $\gamma$ dapat memiliki aktivitas pro-tumor maupun anti-tumor. Penelitian tentang kadar IFN- $\gamma$ asites serta hubungannya dengan subtipe serosa dan non-serosa belum banyak dilakukan.

Tujuan: Mengetahui perbedaan rata-rata kadar IFN- $\gamma$ cairan asites pada subtipe serosa dan non-serosa karsinoma ovarium.

Metode: Penelitian cross sectional selama periode September - Desember 2018. Pengambilan sampel asites dilakukan di kamar operasi RSUP Dr. Sardjito dan pengujian sitokin menggunakan Human IFN- $\gamma$ ELISA Kit dilakukan di Laboratorium Biologi Molekuler FKKMK Universitas Gadjah Mada.

Hasil dan Pembahasan: Pada 11 sampel subtipe serosa didapatkan rata-rata kadar IFN- $\gamma$ sebesar 0,46 pg/ml, sedangkan pada 7 sampel non-serosa didapatkan rata-rata $0,97 \mathrm{pg} / \mathrm{ml}$, namun perbedaan rata-rata tersebut tidak signifikan secara statistik $(p=0,104)$.

Simpulan: Tidak terdapat perbedaan rata-rata kadar IFN- $p$ dalam cairan asites pada subtipe serosa dan non-serosa karsinoma ovarium.
\end{abstract}

Kata Kunci: interferon gamma (IFN- $\gamma$ ), karsinoma ovarium, asites, subtipe histopatologi 


\section{PENDAHULUAN}

Penyebab kematian tertinggi dalam kategori keganasan ginekologis dan menempati urutan kelima penyebab kematian pada wanita di dunia adalah kanker ovarium. Kanker ovarium adalah pertumbuhan sel yang tidak terkontrol di dalam ovarium. Sulitnya deteksi dini, diagnosis, dan penanganan penyakit menyebabkan overall survival (OS) pada pasien kanker ovarium rendah, dengan angka overall 5-year survival dibawah $40 \% .^{1} \mathrm{Di}$ Amerika Serikat diperkirakan terdapat 22.240 kasus baru kanker ovarium dan menyebabkan 14.070 kematian pada tahun $2018 .^{2}$ Di Indonesia, kanker ovarium menempati urutan ke-4 penyebab kematian oleh kanker setelah kanker payudara, kanker serviks, dan kanker kolorektal dengan 10.238 kasus pada tahun 2014. ${ }^{3}$

Hampir semua tumor ovarium baik jinak maupun ganas berasal dari satu dari tiga tipe sel, yaitu sel epitel, sel stromal, dan sel germinal. Kanker ovarium paling banyak adalah tipe epitel, dimana $70 \%$ pasien datang sudah dalam stadium lanjut, dengan angka ketahanan hidup 10 tahun sekitar 15-30\%; sedangkan angka ketahanan hidup untuk stadium awal adalah lebih dari $90 \% .{ }^{4}$ Kanker ovarium tipe epitel merupakan penyakit heterogen dengan berbagai subtipe histologi (histotipe) yang berbeda dalam asal sel, patogenesis, perubahan molekuler, ekspresi gen, dan prognosis. Secara histologis, WHO mengklasifikasikan tumor ovarium tipe epitel menjadi tipe serosa, musinosa, endometrioid, clear cell, seromusin, brenner dan karsinoma yang tidak terdiferensiasi. Saat ini tipe serosa merupakan tipe terbanyak dari kasus karsinoma ovarium, khususnya tipe serosa derajat tinggi menyumbang sebanyak 70\% dari seluruh kasus karsinoma ovarium. ${ }^{5}$ Dari berbagai macam subtipe histologi yang berbeda, karsinoma clear cell adalah subtipe yang memiliki ketahanan keseluruhan terhadap penyakit yang buruk karena menunjukkan respon buruk terhadap kemoterapi berbasis platinum. ${ }^{6}$ Sedangkan subtipe serosa bersifat sangat kemosensitif sehingga dapat menghasilkan angka ketahanan hidup yang lebih tinggi. $^{7}$

Asites adalah manifestasi yang umumnya terkait pada pasien dengan karsinoma ovarium, lebih dari sepertiga pasien datang dengan asites maligna saat terdiagnosis. Onset dan progresivitas asites berhubungan dengan prognosis yang buruk dan penurunan kualitas hidup pasien, asites dapat menyebabkan gejala seperti distensi abdomen, sakit perut, cepat kenyang, dan gangguan sistem pernafasan, gastrointestinal, dan saluran kencing. ${ }^{8}$ Cairan asites mengandung komponen seluler dari sistem imun seperti limfosit serta faktor regulasi seperti sitokin dan kemokin yang merupakan bahan yang ideal untuk mengevaluasi interaksi antara sistem imun host dan sel-sel kanker di lingkungan mikro tumor (TME). Salah satu sitokin yang dapat ditemukan di dalam cairan asites maupun darah adalah IFN- $\gamma$, yang merupakan sitokin esensial dalam imunitas bawaan maupun adaptif. IFN- $\gamma$ memiliki faktor prognosis yang cukup tinggi karena mekanismenya sebagai imunomodulator potent, antiproliferasi, antikanker, dan dapat menginduksi apoptosis sel tumor secara in vivo di berbagai studi. Pada sebuah studi didapatkan hasil bahwa kadar IFN- $\gamma$ yang tinggi pada cairan asites terdeteksi pada karsinoma ovarium stadium lanjut, derajat histologis yang tinggi, dan status pembedahan yang kurang optimal. ${ }^{9}$ Sedangkan pada studi lain menunjukkan 28 dari 37 (44\%) pasien dengan karsinoma ovarium tipe serosa, 12 dari 30 (19\%) pasien dengan karsinoma ovarium tipe musin, dan 23 dari 32 (37\%) pasien dengan karsinoma ovarium tipe lain memiliki kadar IFN- $\gamma$ yang tinggi pada jaringan ovarium. ${ }^{1}$

Penelitian mengenai kadar IFN- $\gamma$ dalam asites pasien karsinoma ovarium masih belum banyak dilakukan, oleh karena itu penelitian ini dilakukan untuk mencari tahu kadar IFN- $\gamma$ dalam asites sebagai faktor prognostik pada subtipe histopatologi serosa dan non-serosa kanker ovarium tipe epitel. Pada penelitian ini peneliti membedakan subtipe histopatologi karsinoma ovarium menjadi subtipe serosa dan non-serosa (musinosa, endometrioid, seromusinosa, Brenner, clear cell, dan undifferentiated) dikarenakan prognosis pada kedua kelompok tersebut yang cenderung berbeda, dimana subtipe serosa secara umum memiliki prognosis yang relatif baik dibandingkan subtipe non-serosa dengan overall survival (OS) yang lebih lama. ${ }^{10}$ 


\section{METODE}

Desain penelitian yang digunakan pada penelitian ini adalah belah lintang (cross sectional). Populasi pada penelitian ini adalah pasien kanker ovarium tipe epitel di RSUP Dr. Sardjito Yogyakarta selama periode September-Desember 2018.

Pengambilan sampel asites dilakukan di kamar operasi RSUP Dr.Sardjito dengan kriteria inklusi penderita kanker ovarium jenis epitel yang menjalani operasi di RSUP Dr. Sardjito, bersedia menjadi subjek penelitian, dan asites dapat diambil. Sedangkan kriteria eksklusi adalah memiliki riwayat keganasan lain, pernah menjalani operasi kanker ovarium sebelumnya, asites atau peritoneal washing tidak dapat diambil, hamil, dan menyusui. Berdasarkan periode dan kriteria, sampel penelitian didapatkan sebanyak 18 sampel. Alat dan bahan yang digunakan dalam penelitian ini adalah Human IFN- $\boldsymbol{\gamma}$ (Interferon gamma) ELISA Kit, syringe, alat sentrifugasi, cryovials, lemari pendingin, microplate reader, incubator $37^{\circ} \mathrm{C}$, automated plate washer, precision single and multi-channel pipette and disposable tips, tabung bersih, tabung Eppendorf, air deionisasi/ terdistilasi.

Analisis data menggunakan independent t-test untuk mengetahui adanya perbedaan rata-rata kadar IFN- $\gamma$ cairan asites pada subtipe histopatologi serosa dan non-serosa karsinoma ovarium.

\section{HASIL DAN PEMBAHASAN}

Dalam rentang waktu pengambilan sampel dari bulan September 2018 sampai dengan bulan Desember 2018, terdapat 18 subjek yang memenuhi kriteria inklusi dan eksklusi. Karakteristik subjek dapat dilihat pada Tabel 1.

Pada variabel menurut IMT didapatkan lebih banyak pasien dengan BMI normal yaitu sebanyak 14 orang $(77,8 \%)$ dibandingkan pasien dengan BMI berlebih (22,2\%). Distribusi usia lebih banyak pada usia $<60$ tahun yaitu sebanyak 13 orang $(72,2 \%)$. Subtipe histopatologi yang didapatkan dari 18 subjek adalah 11 subtipe serosa $(61,1 \%)$ dan 7 subtipe nonserosa (1 musinosa, 1 clear cell, 1 Brenner ganas, 1 endometrioid derajat 2, 3 endometrioid derajat 3). Dari 18 subjek didapatkan lebih banyak pasien dengan derajat tinggi/high-grade dan stadium lanjut, yaitu masing-masing 14 orang $(77,8 \%)$. Untuk kategori pembedahan, sebanyak 7 orang mendapatkan perlakuan pembedahan optimal (61,1\%).

Tabel 1. Karakteristik subjek

\begin{tabular}{|c|c|c|}
\hline Variabel & $\begin{array}{c}\text { Jumlah } \\
\text { Pasien }\end{array}$ & $\begin{array}{c}\text { Persentase } \\
\text { (\%) }\end{array}$ \\
\hline \multicolumn{3}{|l|}{ IMT } \\
\hline Normal & 14 & 77,8 \\
\hline Berlebih/Overweight & 4 & 22,2 \\
\hline Jumlah & 18 & 100 \\
\hline \multicolumn{3}{|l|}{ Usia } \\
\hline$<60$ & 13 & 72,2 \\
\hline$\geq 60$ & 5 & 27,8 \\
\hline Jumlah & 18 & 100 \\
\hline \multicolumn{3}{|l|}{ Derajat } \\
\hline Derajat rendah/Low-grade & 4 & 22,2 \\
\hline Derajat tinggi/High-grade & 14 & 77,8 \\
\hline Jumlah & 18 & 100 \\
\hline \multicolumn{3}{|l|}{ Subtipe Histopatologi } \\
\hline Serosa & 11 & 61,1 \\
\hline Non-serosa & 7 & 38,9 \\
\hline Jumlah & 18 & 100 \\
\hline \multicolumn{3}{|l|}{ Stadium } \\
\hline Awal & 4 & 22,2 \\
\hline Lanjut & 14 & 77,8 \\
\hline Jumlah & 18 & 100 \\
\hline \multicolumn{3}{|l|}{ Pembedahan } \\
\hline Suboptimal & 11 & 61,1 \\
\hline Optimal & 7 & 38,9 \\
\hline Jumlah & 18 & 100 \\
\hline
\end{tabular}

Untuk mengetahui perbedaan rata-rata kadar interferon gamma pada subtipe histopatologi serosa dan non-serosa dilakukan analisis independent t-test yang dapat dilihat pada Tabel 2. Setelah dilakukan uji beda, didapatkan nilai $p$-value sebesar $0,104 \quad(p>0,05)$ untuk subtipe histopatologi serosa dan non-serosa. Hasil ini menunjukkan tidak terdapat perbedaan rata-rata yang signifikan secara statistik pada kedua subtipe histopatologi tersebut. Namun apabila dilihat dari rata-rata kadar IFN- $\gamma$ pada masing-masing subtipe, subtype non-serosa memiliki rata-rata kadar IFN- $\gamma$ dalam asites yang lebih tinggi dibandingkan subtipe serosa. 
Tabel 2. Uji beda independent t-test

\begin{tabular}{lrrrrrr}
\hline & \multicolumn{4}{c}{ Kadar IFN- $\gamma(\mathrm{pg} / \mathrm{ml})$} & \multirow{2}{*}{$\mathbf{t}$} & $\mathbf{p}$ \\
\cline { 2 - 4 } & $\mathbf{N}$ & Mean & SD & & \\
\hline Subtipe Histopatologi & & & & & \\
$\quad$ Serosa & 11 & 0,46 & 0,35 & $-1,725$ & 0,104 \\
$\quad$ Non-serosa & 7 & 0,97 & 0,88 & & \\
\hline
\end{tabular}

Hasil analisis rata-rata kadar IFN- $\gamma$ cairan asites terhadap subtipe serosa dan non-serosa didapatkan nilai signifikansi, yaitu $p=0,104 \quad(p>0,05)$ yang membuktikan bahwa tidak terdapat perbedaan ratarata kadar interferon gamma yang signifikan secara statistik pada subtipe histopatologi serosa dan nonserosa. Tidak adanya perbedaan rata-rata yang signifikan antara dua kelompok subtipe histopatologi tersebut dapat diakibatkan oleh beberapa hal, seperti terbatasnya jumlah sampel yang terkumpul dalam penelitian ini atau tidak adanya hubungan antara kadar IFN- $\gamma$ dalam cairan asites dengan subtipe histopatologi karsinoma ovarium. Namun apabila dilihat dari rata-rata kadar IFN- $\gamma$ cairan asites pada masing-masing subtipe histopatologi, subtipe non-serosa memiliki rata-rata IFN- $\gamma$ sebesar $0,97 \mathrm{pg} / \mathrm{ml}$, sedangkan subtipe serosa sebesar 0,46 $\mathrm{pg} / \mathrm{ml}$, hasil ini menunjukkan bahwa subtipe nonserosa memiliki rata-rata kadar IFN- $\gamma$ yang lebih tinggi. Dari kedua subtipe histopatologi tersebut, subtipe non-serosa dilaporkan memiliki prognosis yang lebih buruk dibandingkan subtipe serosa. ${ }^{10}$ Selain sebagai anti-tumor, IFN- $\gamma$ juga dilaporkan bersifat sebagai pro-tumor. Studi mengenai IFN- $\gamma$ melaporkan bahwa IFN- $\gamma$ membentuk imunogenitas tumor dan merangsang pertumbuhan sel tumor dengan sifat immunoevasive, terlibat erat dalam beberapa mekanisme homeostatik atau mekanisme yang dipicu oleh kanker yang mempromosikan lingkungan mikro tumor yang imunosupresif, ${ }^{11}$ juga menyebabkan respon paradoks dalam sel tumor dan sel host yang memfasilitasi pertumbuhan tumor. ${ }^{12}$

Hasil yang didapatkan dalam penelitian ini sesuai dengan penelitian yang telah dilakukan oleh Chen et al. ${ }^{9}$ yang mengatakan bahwa tidak terdapat perbedaan kadar IFN- $\gamma$ dalam cairan asites yang signifikan secara statistik pada subtipe histopatologi karsinoma ovarium $(p=0,488)$. Begitu pula dengan penelitian yang dilakukan Marth et al. ${ }^{1}$ yang menunjukkan tidak terdapat perbedaan kadar IFN- $\gamma$ dalam cairan asites yang signifikan secara statistik, namun pada penelitian tersebut terlihat bahwa kadar IFN- $\gamma$ yang tinggi pada jaringan ovarium (>median $0,5548 \mathrm{pg} / \mathrm{ml}$ ) lebih banyak didapatkan pada pasien kanker ovarium subtipe non-serosa (musinosa dan lainnya), yaitu sebesar $55,6 \%$ dibandingkan subtipe serosa $(44,4 \%)$.

Subtipe serosa secara umum memiliki prognosis yang relatif baik dibandingkan subtipe histopatologi lainnya. Subtipe non-serosa memiliki OS yang lebih pendek dibandingkan subtipe serosa secara signifikan $(p<0,001)$, dengan 5 -year survival rate $8,5 \%$ dan median survival time 505 hari untuk subtipe non-serosa dibandingkan 37\% dan 1.104 hari untuk subtipe serosa. ${ }^{10}$ Selain itu, subtipe non-serosa secara konsisten berhubungan dengan peningkatan risiko kematian untuk pasien dengan tumor residu suboptimal dibandingkan dengan subtipe serosa. ${ }^{10}$ Banyak peneliti telah menunjukkan bahwa subtipe clear cell dan musinosa, yang termasuk dalam subtipe nonserosa, memiliki prognosis yang jauh lebih buruk daripada subtipe histopatologi karsinoma ovarium stadium IV lainnya. Sebuah studi melaporkan bahwa stadium III/IV dari karsinoma ovarium subtipe musinosa memiliki prognosis yang lebih buruk, dimana median OS untuk subtipe musinosa adalah 14,6 bulan, sedangkan untuk subtipe serosa adalah 47,7 bulan. ${ }^{13}$ Studi lain melaporkan nilai rentang median OS pada subtipe serosa dan subtipe clear cell dengan atau tanpa subtipe musinosa masingmasing adalah 18,2 - 29,3 bulan dan 6 - 14,2 bulan. ${ }^{14}$ Karsinoma ovarium subtipe musinosa juga dilaporkan memiliki tingkat respon terhadap terapi berbasis platinum jauh lebih rendah daripada subtipe serosa. Pada sebuah analisis retrospektif terhadap 27 pasien karsinoma ovarium subtipe musinosa stadium III/IV memiliki tingkat respon terhadap terapi berbasis platinum sebesar $26 \%$ dibandingkan tingkat respon pada subtipe serosa 
yang sebesar $63 \% .{ }^{13}$ Sebuah konsensus general dari berbagai studi retrospektif mengungkapkan bahwa pada stadium lanjut (stadium III/IV), subtipe clear cell juga membawa prognosis yang buruk dengan ketidakpekaan terhadap kemoterapi berbasis platinum dibandingkan subtipe serosa dan lainnya. ${ }^{15}$ Diantara pasien dengan stadium III/IV yang mendapatkan kemoterapi berbasis paclitaxel dan platinum, subtipe clear cell memiliki 5-year survival yang lebih rendah secara signifikan dibandingkan subtipe serosa $(p=0,011) .{ }^{14}$ Sedangkan, subtipe serosa bersifat sangat kemosensitif sehingga dapat memiliki angka ketahanan hidup yang lebih tinggi dibandingkan subtipe histopatologi lainnya. ${ }^{7}$

\section{Keterbatasan Penelitian}

Keterbatasan dari penelitian ini terbatasnya jumlah sampel yang terkumpul, tidak semua sampel menggunakan cairan asites, dan kultur sel tidak dilakukan sehingga tidak mengetahui asal IFN- - .

\section{KESIMPULAN DAN SARAN}

Tidak terdapat perbedaan rata-rata kadar interferon gamma (IFN- $\gamma$ ) cairan asites pada subtipe histopatologi serosa dan non-serosa karsinoma ovarium, walapun subtipe non-serosa cenderung memiliki rata-rata kadar IFN- $\gamma$ yang lebih tinggi.

Perlu dilakukan penelitian serupa dengan jumlah sampel yang lebih banyak, menggunakan cairan asites pada seluruh subjek penelitian, serta melakukan kultur sel sehingga dapat mengetahui asal IFN- $\gamma$.

\section{DAFTAR PUSTAKA}

1. Marth, C., Fiegl, H., Zeimet, A.G., Müller-Holzner, E., Deibl, M., Doppler, W. and Daxenbichler, G., 2004. Interferon- $\gamma$ expression is an independent prognostic factor in ovarian cancer. American journal of obstetrics and gynecology, 191(5), pp.1598-1605.

2. American Cancer Society 2018, Key Statistics for Ovarian Cancer, Atlanta: American Cancer Society, Inc. 2018, viewed 21 April 2018, https://www.cancer. org/cancer/ovarian-cancer/about/key-statistics. html

3. World Health Organization 2014, Cancer Country Profiles, viewed 21 April 2018, https://www.who. int/cancer/country-profiles/idn_en.pdf
4. Ezzati, M., Abdullah, A., Shariftabrizi, A., Hou, J., Kopf, M., Stedman, J.K., Samuelson, R. and Shahabi, S., 2014. Recent advancements in prognostic factors of epithelial ovarian carcinoma. International scholarly research notices, 2014.

5. Reid, B.M., Permuth, J.B. and Sellers, T.A., 2017. Epidemiology of ovarian cancer: a review. Cancer biology \& medicine, 14(1), p.9.

6. World Health Organization, 2014. WHO Classification of Tumors of Female Reproductive Organs. $4^{\text {th }}$ Edition, p.15-40.

7. Mizuno, M., Kajiyama, H., Shibata, K., Mizuno, K., Kawai, M., Nagasaka, T. and Kikkawa, F., 2015. Prognostic value of histological type in stage IV ovarian carcinoma: a retrospective analysis of 223 patients. British journal of cancer, 112(8), p.1376.

8. Ahmed, N. and Stenvers, K., 2013. Getting to know ovarian cancer ascites: opportunities for targeted therapy-based translational research. Frontiers in oncology, 3, p.256.

9. Chen, Y.L., Cheng, W.F., Chang, M.C., Lin, H.W., Huang, C.T., Chien, C.L. and Chen, C.A., 2013. Interferon gamma in ascites could be a predictive biomarker of outcome in ovarian carcinoma. Gynecologic oncology, 131(1), pp.63-68.

10. Hosono, S., Kajiyama, H., Mizuno, K., Sakakibara, K., Matsuzawa, K., Takeda, A., Kawai, M., Nagasaka, T. and Kikkawa, F., 2011. Comparison between serous and non-serous ovarian cancer as a prognostic factor in advanced epithelial ovarian carcinoma after primary debulking surgery. International journal of clinical oncology, 16(5), p.524.

11. Mojic, M., Takeda, K. and Hayakawa, Y., 2017. The dark side of IFN- $\gamma$ : its role in promoting cancer immunoevasion. International journal of molecular sciences, 19(1), p.89.

12. Alspach, E., Lussier, D.M. and Schreiber, R.D., 2018. Interferon $\gamma$ and its important roles in promoting and inhibiting spontaneous and therapeutic cancer immunity. Cold Spring Harbor perspectives in biology, p.a028480.

13. Ricci, F., Affatato, R., Carrassa, L. and Damia, G., 2018. Recent insights into mucinous ovarian carcinoma. International journal of molecular sciences, 19(6), p.1569.

14. Ku, F.C., Wu, R.C., Yang, L.Y., Tang, Y.H., Chang, W.Y., Yang, J.E., Wang, C.C., Jung, S.M., Lin, C.T., Chang, T.C. and Chao, A., 2018. Clear cell carcinomas of the ovary have poorer outcomes compared with serous carcinomas: Results from a single-center Taiwanese study. Journal of the Formosan Medical Association, 117(2), pp.117-125.

15. Tan, D.S. and Kaye, S., 2007. Ovarian clear cell adenocarcinoma: a continuing enigma. Journal of clinical pathology, 60(4), pp.355-360. 